\title{
Incidence of Bacteria-Yeast-Moulds on Processed Jackfruit Squash from Different Genotypes
}

\author{
M.S. Shwetha* and B. Ranganna \\ Department of Agricultural Engineering, University of Agricultural Sciences, G.K.V.K, \\ Bangalore-560-065, Karnataka, India \\ *Corresponding author
}

A B S T R A C T

\begin{tabular}{|l|}
\hline Ke y w o r d s \\
Jackfruit, Genotype, \\
$\begin{array}{l}\text { Squash, Microbial } \\
\text { analysis, Shelf-life, } \\
\text { Storage }\end{array}$ \\
\hline Article Info \\
\hline $\begin{array}{l}\text { Accepted: } \\
\text { 07 January } 2018 \\
\text { Available Online: } \\
\text { 10 February } 2018\end{array}$ \\
\hline
\end{tabular}

Jackfruit (Artocarpus heterophyllus L.) genotypes namely (HV-1, Swarna Halasu, Muttom Varikka, Lalbagh Madhura and HRS) was selected and processed into squash and later analyzed for microbial properties for a period of 3 months at different storage conditions (ambient and refrigerated). The study revealed that the squash stored under refrigerated temperature was free from microorganisms throughout the storage period (3 months) irrespective of genotypes studied, whereas, bacteria, yeast and mould were found after 60 days of storage period at ambient temperature indicating that the shelf-life and quality of squash was only about 45-60 days at ambient storage in all the genotypes studied respectively.

\section{Introduction}

Jackfruit is a nutritious fruit, mostly consumed as a fresh table fruit. It has a very short shelf life of just a day or two after ripening and bulbs have one day after separating from the fruit. In India, except the production of jackfruit chips from unripe fruit in some regions no commercial methods of jackfruit processing into different value added products is in practice. Therefore, there is a trust in recent times, to explore the utilization of this fruit especially through product diversification. Reports suggest that jackfruit pulp can be used as a raw material for the preparation of squash, juice, wine, jam, jelly, candy etc. Further, hardly few research studies have been reported on the product development, storage and preservation of jackfruit bulbs.

Jackfruit (Artocapus heterophyllus L.) bulbs are rich in energy, dietary fiber, minerals and vitamins with high in calories, and is one of the healthy fruits to relish. Squash is a non alcoholic concentrated juice that is usually fruit flavoured made from fruit juice, water and sugar or sugar substitute. Interestingly, it is not possible to convert fruits of all jackfruit genotypes into a variety of products due to 
immense variations of plant types. Hence, an attempt was made to process jackfruit squash from different genotypes viz., HV-1, Swarna Halasu, Muttom Varikka, Lalbagh Madhura and HRS variety with a view to come out with the best genotypes ideally suitable for processing into squash. The present study was carried out to analyze the microbial load on developed jackfruit squash from different genotypes.

\section{Materials and Methods}

\section{Processing of jackfruit into squash}

Five popular jackfruit genotypes, namely, $H V$ 1, Swarnahalasu, Muttomvarikka, Lalbaghmadhura and Horticulture Research Station (HRS) were selected for developing squashes. Matured jackfruits of the above genotypes were procured from UAS, GKVK campus and from jackfruit growers in Doddaballapur Taluk of Bangalore Rural District, Karnataka.

\section{Methodology for preparation of squash}

Squash is the most popular fruit beverage drink in most of the households and contains at least 25 per cent fruit pulp, 40 per cent total soluble solids ( ${ }^{\circ}$ Brix) and 1.0 per cent acidity with $350 \mathrm{ppm}$ potassium meta-bisulphite. It is diluted 3-4 times before serving. The manufacturing process for making jackfruit squash has been standardized.

Well matured and ripe deseeded jackfruit bulbs was washed in hot water and cut into pieces and the same was mashed in a blender/mixer to get pulp (TSS of pulp was recorded). Required quantity of pulp (400-450 $\mathrm{g})$, sugar (1200 g) and citric acid (8-10 g) was added to 1 liter of water to attain 45 per cent pulp, $40^{\circ}$ Brix and 1.2 per cent acidity. The homogeneous contents are boiled @ 80-85 ${ }^{\circ} \mathrm{C}$ for 15-20 min. The contents are cooled and
350 ppm potassium meta-bisulphite was added as a chemical preservative and filtered through a stainless steel filter. The filtrate concentrate was filled into plain heat glass bottles and cork sealed by cork sealing machine. The cork sealed squash bottles was pasteurized in a water bath at $90-95^{\circ} \mathrm{C}$ for $15-20 \mathrm{~min}$ and allowed to stand overnight in ambient condition. These bottles were stored for 2 months at room temperature and 3-6 months at low temperature. The concentrate squash might be served by diluting with water in the ratio of $1: 3$.

\section{Microbial analysis}

The processed jackfruit squashes from five genotypes developed as per FSSAI standards and were analyzed for microbial counts like bacteria, yeast and moulds. The experimental treatments are follows:

During storage study of jackfruit squash samples, the squash was observed at monthly intervals for bacteria, yeast and moulds growth and the counts were taken. The processed jackfruit squash from different genotypes were subjected to microbial analysis by employing Dilution Plate Count Method (Somasegaran and Hoben, 1985).

For enumeration of bacterial counts, a $10 \mathrm{ml}$ sample of jackfruit squash was weighed aseptically and was diluted in $90 \mathrm{ml}$ sterile water and subsequent dilutions were prepared up to $10^{3}$ by transferring $1 \mathrm{ml}$ aliquot from $10^{-1}$ to $9 \mathrm{ml}$ water blank. The filtrates serially diluted to $10^{-1}, 10^{-2}$ and $10^{-3}$ were used for the enumerating population of bacteria, yeasts and moulds by plating on suitable medium in duplicate. The culture media used was Nutrient Agar for bacteria and Potato Dextrose for yeasts and moulds respectively. Required dilution of $1 \mathrm{ml}$ was transferred to sterilized petri plates and $15-20 \mathrm{ml}$ of cultured media was poured to it. The plates were shaken in 
anticlockwise direction to attain uniform distribution of dilution to the culture media. The plates were then allowed to solidify the media and incubated for 3-5 days at $26 \pm 2{ }^{\circ} \mathrm{C}$. The plates were then observed for bacteria, yeast and moulds. The results expressed as total counts or colony forming units (cfu/g of sample) was determined using the following formula:

Total counts, $\quad \log \quad c f u / g=$ No of coloniesX Dilution factor

weight of sample $(\mathrm{ml})$

\section{Statistical analysis}

For the statistical analysis, Factorial Completely Randomized Design (FCRD) was adopted. Observations on various parameters were recorded with three replications. The data were analyzed and main and interaction effects were studied (Sundararaj et al., 1972).

\section{Results and Discussion}

The microbial loads of jackfruit squashes stored under ambient and refrigerated temperatures are presented in Table 1 and 2. Squash developed with 5 different selected jackfruit genotypes stored both under refrigerated and ambient storages was subjected to microbial evaluation at every 1 month interval throughout the storage period to assess the micro-organisms viz., bacteria, yeasts and moulds.

These results are in line with Syed et al., (2012) and finally reported that the bacterial count was increasing with the increase of storage period. Shahanwaz et al., (2009) observed that juice beverages stored in glass bottles and stored at refrigerated condition can retain good quality nutritive values and leading to more extensive shelf-life of the products.

Fig.1 Flow chart for preparation of jackfruit squash

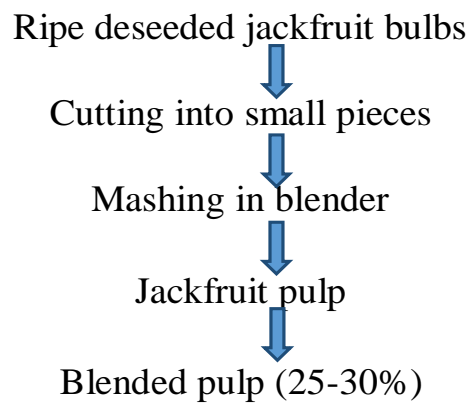

(Water, sugar, citric acid @ 1.0\%, KMS 450 ppm)

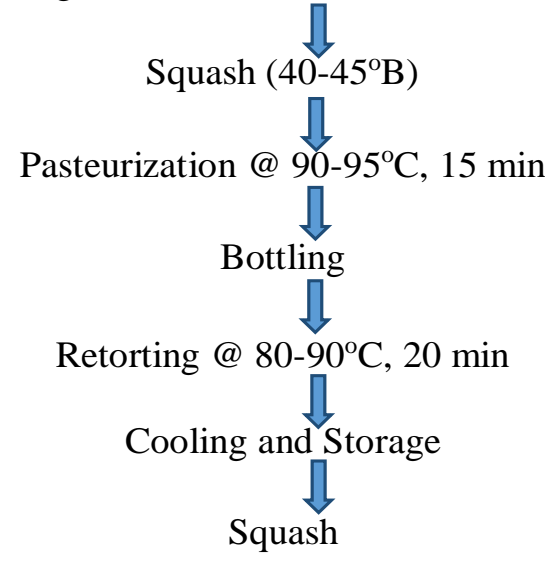


Microbial analysis

\begin{tabular}{|c|l|}
\hline Jackfruit Genotypes $(\mathrm{G})$ & HV-1 (G1), \\
& Swarnahalasu (G2), \\
& Muttomvarikka (G3), \\
& Lalbaghmadhura (G4) and \\
& Horticulture Research Station (HRS) (G5) \\
\hline Packaging material & Glass bottles \\
\hline Preservatives & $\begin{array}{l}\text { Potassium meta-bisulphate (KMS-350 } \\
\text { ppm) }\end{array}$ \\
\hline Storage temperature & $\begin{array}{l}\text { Ambient temperature }\left(\mathbf{2 8}^{-30} \mathbf{O}^{\mathbf{}} \mathbf{C}\right) \\
\text { Refrigeration temperature }\left(\mathbf{2 - 3}^{\mathbf{0}} \mathbf{C}\right)\end{array}$ \\
\hline Storage period $(\mathrm{D})$ & $\mathbf{9 0}$ days $(\mathbf{3}$ months) \\
\hline
\end{tabular}

Table.1 Influence of genotypes on microbial counts of jackfruit squashes during storage

\begin{tabular}{|c|c|c|c|c|c|c|c|c|c|c|}
\hline \multirow{4}{*}{ Genotype (G) } & \multicolumn{10}{|c|}{ Bacteria $(\mathbf{c f u} / \mathrm{g})$} \\
\hline & \multicolumn{10}{|c|}{ Storage period (days) } \\
\hline & \multicolumn{4}{|c|}{$\begin{array}{l}\text { Ambient temperature } \\
\text { (D) }\end{array}$} & Mean & \multicolumn{4}{|c|}{$\begin{array}{l}\text { Refrigerated temperature } \\
\text { (D) }\end{array}$} & \multirow[t]{2}{*}{ Mean } \\
\hline & 0 & 30 & 60 & 90 & & 0 & 30 & 60 & 90 & \\
\hline G-1 & 0.707 & 2.335 & 7.097 & 11.20 & 5.335 & 0.707 & 0.707 & 0.707 & 0.965 & 0.771 \\
\hline G-2 & 0.707 & 0.707 & 2.792 & 5.522 & 2.432 & 0.707 & 0.707 & 0.707 & 0.965 & 0.771 \\
\hline G-3 & 0.707 & 0.707 & 3.315 & 6.314 & 2.761 & 0.707 & 0.707 & 0.707 & 1.224 & 0.836 \\
\hline G-4 & 0.707 & 0.707 & 2.815 & 7.071 & 2.825 & 0.707 & 0.707 & 0.707 & 0.965 & 0.771 \\
\hline G-5 & 0.707 & 0.707 & 3.711 & 7.442 & 3.142 & 0.707 & 0.707 & 0.707 & 0.965 & 0.771 \\
\hline Mean & 0.707 & 1.032 & 3.946 & 7.510 & - & 0.707 & 0.707 & 0.707 & 1.017 & - \\
\hline
\end{tabular}

\begin{tabular}{|c|c|c|c|c|c|c|}
\hline \multirow{2}{*}{$\begin{array}{c}\text { Statistical } \\
\text { analysis }\end{array}$} & \multicolumn{3}{|c|}{ Ambient temperature } & \multicolumn{3}{c|}{ Refrigerated temperature } \\
\hline F-test & $*$ & D & GxD & G & D & GxD \\
\hline SEm \pm & 0.1568 & 0.1402 & 0.3136 & 0.0579 & 0.0518 & $\mathbf{0 . 1 1 5 7}$ \\
\hline CD at 5\% & 0.4625 & 0.4137 & 0.9250 & - & 0.1527 & - \\
\hline CV $(\%)$ & & $\mathbf{1 3 . 4 4 3 0}$ & & & $\mathbf{2 0 . 8 5}$ & \\
\hline
\end{tabular}

* Significant at 5\%, NS - non-significant, $\mathrm{G}$ - genotypes, D - days

Table.2 Influence of genotypes on 'microbial counts' of jackfruit squashes during storage

\begin{tabular}{|c|c|c|c|c|c|c|c|c|c|c|}
\hline \multirow{4}{*}{ Genotype (G) } & \multicolumn{10}{|c|}{ Yeast/moulds (cfu/g) } \\
\hline & \multicolumn{10}{|c|}{ Storage period (days) } \\
\hline & \multicolumn{4}{|c|}{$\begin{array}{l}\text { Ambient temperature } \\
\text { (D) }\end{array}$} & Mean & \multicolumn{4}{|c|}{$\begin{array}{l}\text { Refrigerated temperature } \\
\text { (D) }\end{array}$} & \multirow[t]{2}{*}{ Mean } \\
\hline & 0 & 30 & 60 & 90 & & 0 & 30 & 60 & 90 & \\
\hline G-1 & 0.707 & 1.870 & 5.025 & 8.645 & 4.062 & 0.707 & 0.707 & 0.707 & 0.707 & 0.707 \\
\hline G-2 & 0.707 & 0.707 & 2.989 & 1.973 & 1.594 & 0.707 & 0.707 & 0.707 & 0.965 & 0.771 \\
\hline G-3 & 0.707 & 2.671 & 2.895 & 4.635 & 2.724 & 0.707 & 0.707 & 0.707 & 0.707 & 0.707 \\
\hline G-4 & 0.707 & 0.707 & 2.336 & 8.566 & 3.081 & 0.707 & 0.707 & 0.707 & 0.965 & 0.771 \\
\hline G-5 & 0.707 & 0.707 & 2.989 & 6.314 & 2.679 & 0.707 & 0.707 & 0.707 & 0.965 & 0.771 \\
\hline Mean & 0.707 & 1.332 & 3.248 & 6.027 & - & 0.707 & 0.707 & 0.707 & 0.862 & - \\
\hline
\end{tabular}




\begin{tabular}{|c|c|c|c|c|c|c|}
\hline $\begin{array}{c}\text { Statistical } \\
\text { analysis }\end{array}$ & \multicolumn{3}{|c|}{ Room temperature } & \multicolumn{3}{c|}{ Refrigerated temperature } \\
\hline F-test & $*$ & $\mathbf{D}$ & $\mathbf{G} \times \mathbf{D}$ & $\mathbf{G}$ & $\mathbf{D}$ & $\mathbf{G \times D}$ \\
\hline SEm \pm & 0.3442 & 0.3097 & 0.6884 & 0.0501 & NS & NS \\
\hline CD at 5\% & 1.0153 & 0.9081 & 2.0306 & - & - & $\mathbf{0 . 1 0 0 2}$ \\
\hline CV $(\%)$ & & $\mathbf{3 4 . 4 1}$ & & & $\mathbf{1 9 . 0 0}$ & - \\
\hline
\end{tabular}

* Significant at 5\%, NS - non-significant, G - genotypes, D - days

Microbial analysis indicated that in all the five genotypes of jackfruit squash, bacteria, yeast and moulds were noticed after 1 month of storage period, but the squash was found acceptable as the microbial counts were within the recommended level. Also, as storage period increased the micro-organism load was found increasing i.e., after 2 months at ambient storage. However, squashes from 5 different genotypes stored in refrigerated storage were found to be free from microbial load besides, retaining all their quality attributes respectively.

\section{References}

Shahanwaz, M., Sheikh, A. S. and Nizamani, M. S. 2003. Determination of nutritive values of jamun fruit (Eugenia jambolana products). Pak.J. Nutri., 8(8):1275-1280.

Somasegaran Padmanabhan and Hoben J. Heinz. 1985. Methods in Legume Rhizobium Technology. In: Handbook for Rhizobia. Springer-Verlag publishers-Netherlands. pp 450.

Sundararaj, N., Nagaraju, S., Venkataramana, M N and Jagannath, M K. 1972. Design and analysis of field experiments, University of Agricultural Sciences, Bangalore.

Syed, H M., Ghatge, P.U., Machewad, G. and Pawar, S. 2012. Studies on preparation of Squash from Sweet Orange. Scientific reports.1:311.

\section{How to cite this article:}

Shwetha, M.S. and Ranganna, B. 2018. Incidence of Bacteria-Yeast-Moulds on Processed Jackfruit Squash from Different Genotypes. Int.J.Curr.Microbiol.App.Sci. 7(02): 775-779. doi: https://doi.org/10.20546/ijcmas.2018.702.098 